\title{
IMPROVING LEARNING OUTCOMES OF PHYSICAL EDUCATION USING MULTIMEDIA TECHNOLOGY IN 4.0 ERA

\author{
Mashari ${ }^{1}$, Adi $\mathrm{S}^{2}$ \\ ${ }^{1}$ SMAN 4 Bojonegoro \\ ${ }^{2}$ Universitas Nahdlatul Ulama Sunan Giri Bojonegoro \\ Email: harimas397@gmail.com
}

\begin{abstract}
This research is based on physical education learning outcomes that are still low. The research aims to improve learning outcomes of badminton. The subjects of this study were students of class XI IPS SMAN 4 Bojonegoro. The number of samples in this study were 36 students. This study uses classroom action research with two cycles with a multimedia technology approach. Based on the results of the study before the action the average student score of 40 (not good); in the first cycle learning outcomes an average of 60 (enough); and in cycle II the average value is 80.45 (good) and classical completeness is 36 students or 100\%. The use of multimedia technology has succeeded in increasing physical education learning outcomes. The latest multimedia facilities can answer problems that arise in learning. The effectiveness of multimedia learning can be seen from its tendency to attract the attention and interests of students because it combines views, sound and movement. So that learning takes place interesting and easy to remember by students.
\end{abstract}

Keywords: Multimedia, Physical Education, Learning Outcomes

\section{INTRODUCTION}

Education is ideally in accordance with the talents and abilities of students. In order to achieve good education it is necessary to develop a school life environment as a learning environment that is safe, honest, full of creativity, and friendship, as well as with a high sense of nationality and strength (Omeri, 2015). Schools and extracurriculars can help students achieve their dreams as a basis for fostering student sports so students understand each other, and generate self-confidence (Rasyono, 2016). Menurut (Arifin, Fallo, \& Sastaman, 2017; Hernado, Soekardi, \& Lestari, 2017), sport is a systematic process aimed at fostering one's potential in the context of the formation of a whole person. In line with the above (Nurseta \& Soenyoto, 2017), sports are held in stages, gradually and continuously. Sports within the scope of the school develop students in physical aspects which aim at the formation of a whole person. 
Multimedia as the most commonly used simple form is defined as content presentation using a combination of media [text, sound, images (static, motion, animation, video)] (Munir, 2013). Appropriate resources and technology as learning facilities for students as well as practical activities that able to facilitate educational activities with technological processes referred to as educational technology (Kiat, Halim, \& Ibrahim, 2015). Technology that includes physical education as a tool in the form of learning with information theory and psychomotor quality is considered to be motivational and it increases interaction between teachers and students. Technology is needed in, developing learning model in physical education.

Teachers must have sufficient knowledge and follow the latest situation related to technology in approaching using perspective through a broader range to support the design of integration of educational technology that can benefit students and civilize learning based on technology (Szeto, Cheng, \& Hong, 2015). The principle in the implementation of multimedia learning will occur if we design a mental representation by uniting text and graphic elements in accordance with the form of learning (Kari Jabbour, 2012). Using methods such as multimodal interactive information delivery; personalized can be used and accessed anywhere and anytime (Malik \& Agarwal, 2012). Multimedia aims to present information that can be received by students in the form of fun, interesting, easy to understand, and clear content (Suwiwa, Santyasa, \& Kirna, 2014). Multimedia design in learning combines audio, text and graphic elements to enhance the effectiveness of learning. The use of multimedia instruction can help students involved in active learning to achieve the objectives of the learning.

When there are problems and obstacles faced by teachers in their classrooms, such as poor learning, low learning outcomes and even less motivated students, the teacher must try to find a solution. One effective way is to carry out classroom action research or learning improvement. These obstacles are found in badminton material.

Based on observations found that, students do not seem eager to learn. This can be seen from the average value of 40 with the number of individuals 9 people or $25 \%$ who have finished learning. Based on the identification contemplated by the authors, the perceived problems in learning are: (1) learning that is too abstract; (2) the lack of students having textbooks and the lack of interest in learning; (3) lack of students repeating lessons at home; (4) learning methods that rely solely on lectures: and (5) lack of use of learning media so that learning is less attractive to students. The writer as a teacher feels responsible for overcoming the low learning outcomes. From the identification of the learning problems above, the author's analysis of the main causes 
of the problem is the lack of use of instructional media that is currently in accordance with the demands of the times.

\section{METHOD}

The subjects of this class action research were all students of class XI IPS 1 of SMAN 4 Bojonegoro. The number of students is 36. This class action research was conducted in the 2019 school year in the odd semester. The research was carried out in two cycles. While the material to be taken is the subject of physical education. Each cycle consists of four stages. The intended sequence of steps is planning, implementing, observing, and reflecting. The multimedia used in this research is multimedia based on World Electric Browser. This multimedia is accessed on the amongrogo.com page. Before conducting research, the teacher checks the smartphone and the availability of signals in the learning area. Analysis of the data that researchers use is:

$$
x=\frac{F}{N}
$$

Information:

$\mathrm{X}=$ Score

$\mathrm{F}=$ Correct Score

$\mathrm{N}=$ Total Score

After the improvement data is obtained, then the data is classified or categorized according to the assessment guidelines in teaching, namely:

Table 1. Intervals and Categories of Physical Education Learning Absorption

\begin{tabular}{cc}
\hline Interval & Category \\
\hline $85-100$ & Very good \\
$70-84$ & Well \\
$50-69$ & Pretty good \\
$0-49$ & Not good
\end{tabular}

\section{FINDINGS AND DISCUSSION}

The results of physical education improvement in the improvement of cycle I and II by using graphical media are shown in the following table:

Tabel 2. Results of physical education improvement in Cycle I and II

\begin{tabular}{cccccc}
\hline $\begin{array}{c}\text { Total } \\
\text { Students }\end{array}$ & $\begin{array}{c}\text { Learning } \\
\text { Improvement }\end{array}$ & Average & $\begin{array}{c}\text { Individual } \\
\text { Completeness }\end{array}$ & $\begin{array}{c}\text { Classical } \\
\text { Completeness }\end{array}$ & Category \\
\hline \multirow{2}{*}{36} & Preliminary data & 40 & 9 & $25 \%$ & Not Good \\
& Cycle 1 & 60 & 20 & $55 \%$ & Pretty Good \\
& Cycle 2 & 84 & 36 & $100 \%$ & Good \\
\hline
\end{tabular}


From the analysis of the data above, seen from the preliminary data, only 9 students completed with an average grade of 40 in poor categories. After making improvements in the first cycle, student learning outcomes are much improved compared with the initial data score. The mean value obtained by students in cycle 1 is 60 with a fairly good category. Individual completeness was 20 students, and classical class completeness increased to 55\%. But it hasn't been said to be successful. The reason for this unsuccessful improvement was due to lack of understanding of the material. This is because the writer is too quick to explain or explain the learning material. For that reason, the writer does cycle II.

In cycle II, student learning outcomes increased again when compared with the initial data acquisition and the value of cycle I. Where the average value obtained by students in cycle II was 84 with a good category with individual completeness of 36 students or had reached $100 \%$ classical completeness.

Students are more active and easier to understand learning outcomes compared to cycle I, teachers are easier to convey, knowledge is easier for students to obtain, and learning outcomes improve. But there is no method that does not have weaknesses, as well as the use of multimedia, the weakness is that too much time is needed, students still need time to adapt and the ability of each device is different in receiving energy. Multimedia is more easily understood by students because learning material is seen in a concrete or real way. In cycle II, learning is more easily understood by students. This happens because you have already experienced learning visually. In this cycle, the writer also understands how to learn it.

Based on the initial learning outcomes, cycle I, and cycle II, there was a significant increase in classical learning outcomes. The improvement in learning outcomes is clearly seen in the following chart:

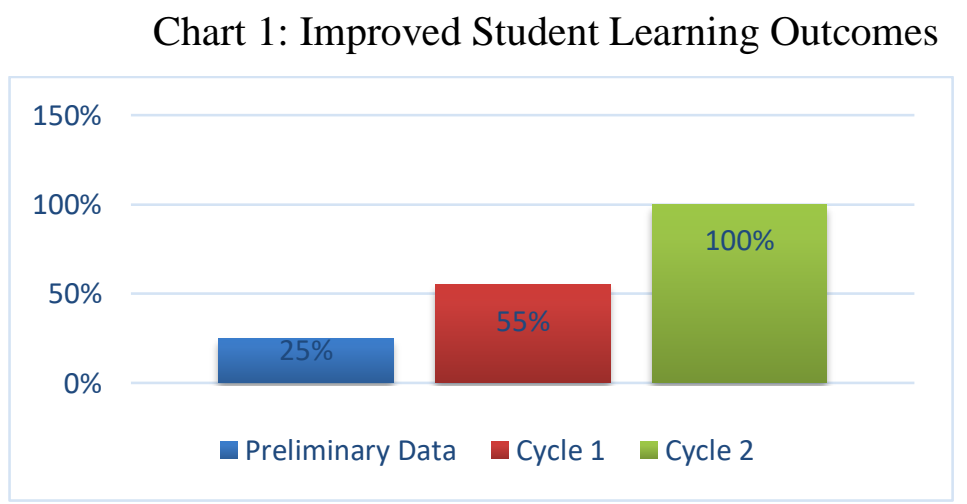

The acquisition of learning outcomes through the senses of sight and hearing is very significant of $90 \%$. If it is only using the sense of hearing, the acquisition of learning outcomes is 
$5 \%$ and the other senses also obtain 5\% (Elpira \& Ghufron, 2015). The effectiveness of multimedia can be seen from several advantages of multimedia, as follow:

- The use of some medias in providing information.

- The ability to access information up to date and provide deeper and more information.

- It is multi-sensory because it stimulates a lot of senses. Thus, it leads to attention and a good level of retention.

- It attracts attention and interest because it is a combination of views, sound and movement. Moreover, humans have limited memory.

- Alternative media in the delivery of messages reinforced by text, images, sound, video and animation.

- Improving the quality of information delivery.

- Being interactive creates a two-way relationship between multimedia users (Munir, 2013).

The learning that currently can be accessed by wider community, especially by all students. It should always develop and innovate with creativity in the use of technology as a learning medium adapted to science and technology (Surahman \& Surjono, 2017). Innovated creativity can be developed into interactive multimedia for learning. Interactive multimedia as an effective learning media are: 1) deliver material that is not always using verbalism; 2) overcoming the limitations of space, time, energy and sense power; 3) generating enthusiasm for learning, more direct interaction between students and learning resources: 4) enabling children to learn independently according to their talents and visual, audio and kinesthetic abilities and 5) providing the same stimuli by uniting experiences (Jamilah, Raharjo, \& Samsudi, 2012). Some of the advantages of learning to use multimedia than others are that there is no need to print or hard copy and can be made/edited while teaching. It makes the teacher easier and more efficient in presenting the material. Multimedia that is developing nowadays has a great opportunity to become a learning and alternative tool for students (Arfan, Wilopo, \& Wahyuni, 2010). The use of instructional media with multimedia will make students to able to study anywhere and anytime while teachers are not available or limited.

\section{CONCLUSIONS}

The use of multimedia technology has succeeded in increasing physical education learning outcomes. The latest multimedia facilities can answer problems that arise in learning. The effectiveness of multimedia learning can be seen from its tendency to attract the attention and interests of students because it combines views, sound and movement. So that learning takes 
place interesting and easy to remember by students. Multimedia also allows students to be more active.

\section{REFERENCES}

Arfan, M., Wilopo, S. A., \& Wahyuni, B. (2010). Efektivitas Pendidikan Kesehatan Melalui EFile Multimdia Materi KRR Dan Tatap Muka Di Kelas Terhadap Peningkatan Effectivnes Of Health Education Through Multimedia E-file And. Berita Kedokteran Masyarakat, 26(3), 107-114. https://doi.org/10.1109/WAINA.2013.176

Arifin, Z., Fallo, I. S., \& Sastaman, P. (2017). Identifikasi bakat olahraga siswa sekolah dasar di Pontianak Barat. Jurnal Pendidikan Olahraga, 6(2), 129-139.

Elpira, N., \& Ghufron, A. (2015). Pengaruh Penggunaan Media Powerpoint Terhadap Minat Dan Hasil Belajar Ipa Siswa Kelas Iv Sd. Jurnal Inovasi Teknologi Pendidikan, 2(1), 94-104. https://doi.org/10.21831/tp.v2i1.5207

Hernado, F., Soekardi, \& Lestari, W. (2017). Pengaruh Metode Latihan dan Power Otot Lengan terhadap Hasil Tolak Peluru. Journal of Physical Education and Sports, 6(1), 22-28. Retrieved from http://journal.unnes.ac.id/sju/index.php/jpes

Jamilah, Z., Raharjo, T., \& Samsudi. (2012). Keefektifan Multimedia Interaktif Dalam Meningkatkan Hasil Belajar Pada Mata Pelajaran Menggambar Busana Siswa Smk Negeri 6 Semarang. Innovative Journal of Curriculum and Educational Technology, 1(1).

Kari Jabbour, K. (2012). Multimedia Principle in Teaching Lessons. Acta Didactica Napocensia, $5(4), 11-16$.

Kiat, L., Halim, N., \& Ibrahim, H. (2015). Issues and future trends in teaching physical education: A preliminary study. https://doi.org/10.1109/IC3e.2015.7403490

Malik, S., \& Agarwal, A. (2012). Use of Multimedia as a New Educational Technology Tool-A Study. International Journal of Information and Education Technology, 2(5), 468-471. https://doi.org/10.7763/ijiet.2012.v2.181

Munir. (2013). Multimedia Konsep dan Aplikasi dalam Pendidikan. Bandung: Alfabeta.

Nurseta, H., \& Soenyoto, T. (2017). Journal of Physical Education and Sports Manajemen Pelaksanaan POPDA SMP / MTs dan SMA / SMK / MA Tingkat Kabupaten Pemalang Tahun 2015 Abstrak. 6(2), 157-164.

Omeri, N. (2015). Pentingnya Pendidikan Karakter Dalam Dunia Pendidikan. Manajer Pendidikan, 9(3), 464-468.

Rasyono. (2016). Ekstrakurikuler Sebagai Dasar Pembinaan Olahraga Pelajar. Journal of Physical Education Health and Sport, 3(1), 44-49. https://doi.org/10.15294/jpehs.v3i1.6501

Surahman, E., \& Surjono, H. D. (2017). Pengembangan adaptive mobile learning pada mata pelajaran biologi SMA sebagai upaya mendukung proses blended learning. Jurnal Inovasi Teknologi Pendidikan, 4(1), 26. https://doi.org/10.21831/jitp.v4i1.9723

Suwiwa, I. G., Santyasa, I. W., \& Kirna, I. M. (2014). Pengembangan Multimedia Interaktif 
Pembelajaran Pada Mata Kuliah Teori Dan Praktik Pencak Silat. E-Journal Program Pascasarjana Universitas Pendidikan Ganesha, 4.

Szeto, E., Cheng, A., \& Hong, J.-C. (2015). Learning with Social Media: How do Preservice Teachers Integrate YouTube and Social Media in Teaching? The Asia-Pacific Education Researcher, 25. https://doi.org/10.1007/s40299-015-0230-9 